\title{
Evolution of the big deals use in the public universities of the Castile and Leon region, Spain
}

\author{
Andrés Fernández-Ramos; Blanca Rodríguez-Bravo; María-Luisa Alvite-Díez; Lourdes \\ Santos-De-Paz; María-Antonia Morán-Suárez; Josefa Gallego-Lorenzo; Isabel Olea
}

Nota: Este artículo se puede leer en español en:

http://www.elprofesionaldelainformacion.com/contenidos/2019/nov/fernandez-rodriguez-alvite-santos-moran-gallego-olea_es.pdf

How to quote this article:

Fernández-Ramos, Andrés; Rodríguez-Bravo, Blanca; Alvite-Díez, María-Luisa; Santos-De-Paz, Lourdes; Morán-Suárez, María-Antonia; Gallego-Lorenzo, Josefa; Olea, Isabel (2019). "Evolution of the big deals use in the public universities of the Castile and Leon region, Spain". El profesional de la información, v. 28, n. 6, e280519. https://doi.org/10.3145/epi.2019.nov.19

Manuscript received on June, $19^{\text {th }} 2019$ Accepted on September, 24 2019

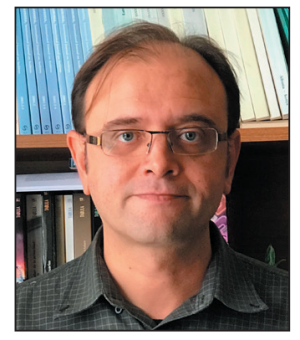

Andrés Fernández-Ramos http://orcid.org/0000-0002-6869-602X

Universidad de León Facultad de Filosofía y Letras Área de Biblioteconomía y Documentación Campus de Vegazana, s/n.

24071 León, Spain

afernr@unileon.es

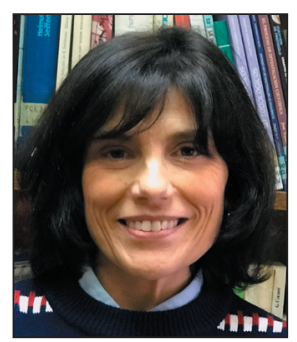

\section{María-Luisa Alvite-Díez}

http://orcid.org/0000-0003-1490-8936

Universidad de León

Facultad de Filosofía y Letras

Área de Biblioteconomía y Documentación

Campus de Vegazana, s/n.

24071 León, Spain

luisa.alvite@unileon.es

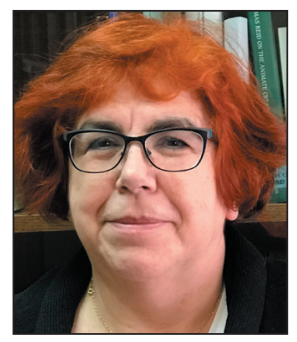

María-Antonia Morán-Suárez http://orcid.org/0000-0003-1954-5783

Universidad de León

Facultad de Filosofía y Letras

Área de Biblioteconomía y Documentación

Campus de Vegazana, s/n.

24071 León, Spain

mamors@unileon.es

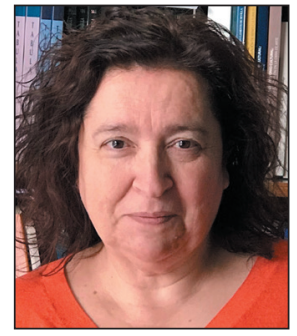

Isabel Olea

http://orcid.org/0000-0002-4989-790X

Universidad de León

Facultad de Filosofía y Letras

Área de Biblioteconomía y Documentación

Campus de Vegazana, s/n.

24071 León, Spain

isabel.iolea@gmail.com

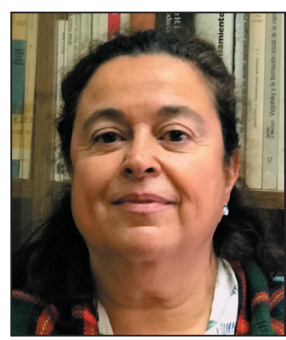

Blanca Rodríguez-Bravo $\square$ http://orcid.org/0000-0002-9476-7602

Universidad de León Facultad de Filosofía y Letras

Área de Biblioteconomía y Documentación

Campus de Vegazana, $\mathrm{s} / \mathrm{n}$.

24071 León, Spain

blanca.rodriguez@unileon.es

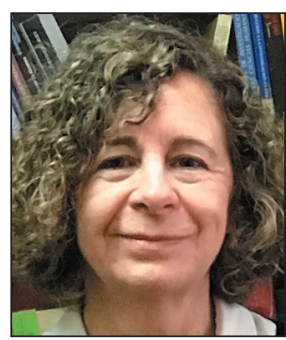

\section{Lourdes Santos-De-Paz}

http://orcid.org/0000-0002-3223-7489

Universidad de León

Facultad de Filosofía y Letras

Área de Biblioteconomía y Documentación

Campus de Vegazana, s/n.

24071 León, Spain

lourdes.santos@unileon.es

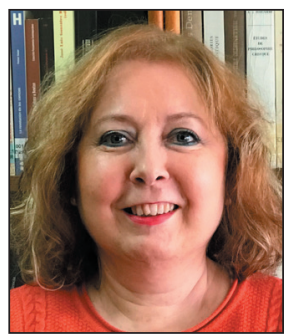

Josefa Gallego-Lorenzo http://orcid.org/0000-0002-5218-517X

Universidad de León

Facultad de Filosofía y Letras

Área de Biblioteconomía y Documentación

Campus de Vegazana, s/n.

24071 León, Spain

josefa.gallego@unileon.es 
Funding

This research has been funded by the Programa Estatal de Investigación, Desarrollo e Innovación Orientada a los Retos de la Sociedad 2017 (the State Research, Development and Innovation Program for the Challenges of the Society 2017), convened by the Ministerio de Economía, Industria y Competitividad (Spanish Ministry of Economy, Industry and Competitiveness) and the Agencia Estatal de Investigación (Spanish State Research Agency) (CSO201787956-R) and by the grant program aimed at supporting the accredited research groups of public universities of Castile and Leon started in 2018, convened by the Consejería de Educación de la Junta de Castilla y León (Ministry of Education of the Castile and Leon regional government) (LE028G18).

\begin{abstract}
The evolution of the use of electronic scientific journals in the 2007-2018 period by the academic communities of the public universities of Castilla and Leon, members of the Bucle consortium, is studied. Downloads of articles distributed by four broad-spectrum providers are analyzed: Emerald, ScienceDirect, SpringerLink, and Wiley. Unexpectedly, in spite of the new ways of accessing content, this analysis shows that the number of downloads in public universities in Castile and Leon has increased. However, it has been found that despite the growth, a few journals concentrate most of the downloads and that a large number of titles are not used. It has been verified that the universities with a higher number of staff and greater diversity of knowledge areas use a wider range of titles and thus obtain a higher benefit from their contracts. All of the above leads us to question the system of contracting big deals, i.e., bundles of hundreds of multidisciplinary journals and other resources. In a moment of change promoted by Plan S, we consider it more necessary than ever to understand the situation of the provision of serial scientific publications and to find the best strategy to have access to them.
\end{abstract}

\title{
Keywords
}

Access to scientific information; Statistics; Downloads; Use of journals; Electronic journals; Scientific journals; Universities; University libraries; Academic libraries; Collection management; Big deals; Bucle Consortium; Castile and Leon; Spain.

\section{Introduction}

The need of researchers to access a broad collection of electronic journals means that university libraries have to assign a high allocation of their budget to cover costs, and therefore, most of their budget is spent on the subscription of electronic resources (Dempsey; Malpas; Lavoie, 2014). This circumstance, added to the fact that subscriptions prices keep increasing while library budgets continue to decrease, makes assessment essential to better understand if the journals are fulfilling the needs of the university community.

Over time, libraries have used various factors to manage their journal collections: impact factor or other indicators; user opinions and recommendations; or the usage data of the journals (Blecic et al., 2013). However, comparing the adequacy of the collection to the needs of users and analyzing its profitability is a complex task that involves interrelating different variables, such as the quantity and quality of the content offered, the resources use, cost, and its contribution to the acchievement of the institution's objectives, which is usually linked to scientific productivity (Coughlin; Campbell; Jansen, 2016; Rodríguez-Bravo et al., 2012; Rodríguez-Bravo; Alvite-Díez, 2013).

There are different ways of approaching an analysis of electronic journal use -one of the main variables when assessing the suitability of the collection to users- since it is an activity that is difficult to observe directly and quantify objectively (Chew et al., 2016). Although there are others, the most commonly used indicator is downloads (Duan; Xiong, 2017; Rodríguez-Bravo; Alvite-Díez, 2011; Rodríguez-Bravo; Alvite-Díez; Barrionuevo-Almuzara, 2012; Rodríguez-Bravo; Alvite-Díez, 2006a; Stemper; Jaguszewski, 2003; Urbano et al., 2004; Wang; Fang; Sun, 2016; Zhu; Xiang, 2016); since this method offers information about which journals are used the most, it can be combined with an analysis of the citation count (Belter; Kaske, 2016; Martin et al., 2016; McDonald, 2007; Shu et al., 2018) or costs of the publications (Arthur, 2018; Bucknall; Bernhardt; Johnson, 2014; Martin et al., 2016; Tetteh, 2018) to have a more precise view on each journal's usefulness and profitability. The analysis of downloads has allowed to study in depth the distribution of the use of electronic journals subscribed by libraries, since it is assumed that not all journals are used with the same frequency.

One of the biggest advantages of the download analysis is that it can be completed in a standardized way. This is thanks in part to the efforts and initiatives of libraries and organizations such as the International Coalition of Library Consortia and the National Information Standards Organization. In addition, the gold standard for measuring the use of electronic journals is the project Counter (Counting Online Usage of NeTworked Electronic Resources) which uses download metrics 
commonly referred to as Sftar (Successful full-text article request) (Blecic et al., 2013).

https://icolc.net

https://www.niso.org

https://www.projectcounter.org

However, download statistics as a measure of journal use should be analyzed with some caution (Boots et al., 2007). These measurements only tell us if an article has been downloaded, but do not tell us if it was read, if it was of interest, or if it was useful for teaching or research. Nevertheless, its usefulness as a starting point for the evaluation of collections is widely recognized and is considered the most reliable information on the use of electronic journals (Blecic et al., 2013).

In the abundant bibliography published on the evolution of article downloads, a continued growth in the use of electronic journals has been observed (Boukacem-Zeghmouri; Schöpfel, 2008; Boukacem-Zeghmouri et al., 2016; Gorraiz; Gumpenberger; Schlögl, 2014; Rodríguez-Bravo; Alvite-Díez, 2011; Rodríguez-Bravo; Alvite-Díez; Barrionuevo-Almuzara, 2012; Rodríguez-Bravo et al., 2008; 2012; Tripathi; Kumar, 2014; Tetteh, 2018). This has been driven by the adoption of the big deal license model, which allows researchers to have access to huge amounts of scientific articles that would be difficult to obtain otherwise. An increase in downloads should be valued positively, since there are studies that have shown a correlation between the number of downloads and the productivity of researchers (Jung et al., 2015; Rafi; JianMing; Ahmad, 2019).

Research has uncovered that the majority of article downloads are from a limited number of journals. Specifically, the distribution of downloads largely conforms to the Pareto principle (Emrani; Moradi-Salari; Jamali, 2010; Schöpfel; Leduc, 2012; Singson; Hangsing, 2015; Srivastava; Kumar, 2018; Zhu; Xiang, 2016). This principle, known for a long time in the management of services and printed collections in libraries (Britten, 1990; Trueswell, 1969), establish an 80/20 distribution between two variables, so that $20 \%$ of one of them explains $80 \%$ of the other (Nisonger, 2008). In the case of the use of electronic journals it means that approximately $80 \%$ of downloads are from $20 \%$ of the contracted titles. These assessment methods identify which journals are necessary for the collection of a library and which may be expendable; results can be used to make informed decisions about renewal or cancellation of subscriptions and even to estimate the profitability of journal packages offered by large providers to library consortiums. In addition, the long-tail theory, formalized by Anderson (2006), indicates that by paying attention to the small but numerous market niches, data can be used to design strategies aimed at effectively disseminating resources that are used less frequently (Dempsey, 2006; Kostagiolas; Korfiatis; Poulos, 2012).

In the first two decades of the $21^{\text {st }}$ century, the big deal formula led to the consolidation of collections for large, medium, and small university libraries, which facilitated access to a volume of content that was previously unimaginable. We believe this model has endured because the complete commercialization of the products of a publisher paved a permanent relationship between publisher-library-user. It is easy for publishers to include their entire catalog, including the titles that are popular and those that are not. As Shu et al. (2018) highlighted, big commercial publishers have increased their journal portfolio through mergers and purchases of other publishers, as well as creating new journals. By including secondary journals in the big deals, publishers have been able to increase the sales and, ultimately, convert academic publishing into a more profitable business.

For libraries, this model has made it possible to overcome the crisis that journals experienced in the 1990s and increase the size of collections, obtaining an average price per subscribed journal that is lower than paper subscriptions. Likewise, for both publishers and libraries it is easier to maintain a more stable relationship without annual negotiations or detailed purchases per title. In this way, the library has eliminated administrative work, however, the management and negotiation of licenses and electronic resources is far from simple (University of California, 2019; Williams, 2010).

Nowadays libraries are immersed in transformation processes of their journal collections. On the one hand, the big deal model is being questioned, because suppliers offer closed bundles of titles that in many cases do not meet the needs of users, as evidenced by the fact that a high percentage of journals are not used. In addition, libraries have serious difficulties in comparing and negotiating the prices of subscriptions to these bundles under optimal conditions, due to confidentiality policies libraries unable to find out what other customers are charged for the same product (Bergstrom et al., 2014; Boukacem-Zeghmouri et al., 2016; Blecic et al., 2013; Frazier, 2005; Shu et al., 2018).

Likewise, access to scientific information is undergoing profound transformations due to the emergence of new channels for the dissemination of research papers, such as repositories and social networks such as ResearchGate (Meier; Tunger, 2018). In addition, there are illegal platforms that offer access to millions of publications, such as Sci-Hub (Nicholas et al., 2019).

Another factor that adds to the transformation is the consolidation of the open access movement and the policies aimed at ensuring that results of research paid with public funds are published in open access (Borrego; Anglada, 2016; Jamali; Nabavi, 2015; Nicholas et al., 2017). Recently, some countries and regions have
The big deal model is being questioned because providers offer closed packages of journal titles that in many cases do not meet the needs of users 
chosen to abandon their subscriptions to big deals; the University of California and universities in Sweden and Germany have not reached renewal agreements for ScienceDirect with Elsevier and in France universities have not reached an agreement with Springer. Similarly, in February 2018, the Canadian Association of Research Libraries published a report that described subscription costs as unsustainable and stated that a solution will require a coordinated national approach against the increase in journal prices (Kwon, 2018).

In general there is the belief that the big deal model is not as profitable as it was for universities. As Schonfeld (2019) points out, in mature markets there is a decrease in download figures from providers due to the leakage of accesses to platforms such as Sci-Hub or ResearchGate.

In this context, and after enough period of operation of the subscription model to scientific journals based on big deals, we consider necessary to analyze the evolution and current status of the use of scientific journals subscribed by university libraries and see to what extent the current subscription models adapt to the new economic context, to the new models of access to scientific information and to the real needs of users (Armstrong; Teper, 2017).

\section{Objectives and methodology}

The general objective of this work is to analyze the evolution of the use of electronic scientific journals between 2007 and 2018 at the public universities of Castile and Leon, members of the Consorcio de Bibliotecas Universitarias de Castilla y León (Consortium of University Libraries of Castile and Leon, Bucle). The time period of this study has been limited to the moment of the consolidation of the use of journals in electronic format by the academic community until the period of change of paradigm that promotes open access for scientific content.

The specific objectives are:

- To describe the usage of electronic journals using article downloads from the platforms under study.

- To compare the use of journals between universities.

- To study the concentration of use of the subscribed content in the different universities.

- To analyze the relationship between potential users and downloads.

- To compare used content to the overall available content.

- To evaluate the use of journal bundles at the four public universities of Castile and Leon.

To achieve the stated objectives, we analyzed the downloads of articles from scientific journals at the universities of Burgos (UBU), León (ULE), Salamanca (USAL), and Valladolid (UVA) provided by four multidisciplinary publishers: Emerald, ScienceDirect, SpringerLink, and Wiley.

In order to study the use of scientific journals, a series of indicators was established and grouped into two blocks:

a) Downloads of articles from the subscribed journals.

- Total annual downloads per university.

- Annual downloads per provider.

- Relationship between downloads and size of universities.

b) Used journal titles.

- Annual evolution of the subscribed titles / used titles.

- Representativeness of the preferred titles over the total downloads in each of the universities.

- Representativeness of $50 \%$ of the downloads over all the titles subscribed to and titles used in each university.

The downloads data studied are those supplied by the providers of electronic journals to the libraries of the public universities of Castile and Leon in the period 2007-2018. The study was developed based on the reports provided by Counter journal report 1 (JR1- Number of successful full-text article requests by month and journal). These are annual Excel files with detailed data on monthly downloads of full-text articles broken down by journal titles and differentiating the access to the pdf and html versions. In this work the two types of access have been aggregated. In January 2014, Counter version 4 entered into effect, providing reports with individualized data on the use of open access journal articles (Gold $O A$ ), as well as retrospective collections (backfiles), data that for this evolutionary study was not analyzed. Since 2017, the JR1 reports on Emerald and Springer have only included the titles used; therefore, in order to collect the data about the subscribed titles, those responsible for acquisitions of the respective institutions were consulted, and they in turn had to request this data from their providers.

Table 1 shows, for each university, the total amount of faculty, including both indefinite and temporary contracts, and full-time and part-time. Excel files accessible from the website of the Ministerio de Ciencia, Innovación y Universidades (Ministry of Science, Innovation and Universities) have been used.

http://www.educacionyfp.gob.es/servicios-al-ciudadano-mecd/estadisticas/educacion/universitaria/estadisticas/ personal-universitario.htm 
Table 1. Research staff of the public universities of Castile and Leon

\begin{tabular}{|c|c|c|c|c|c|c|c|c|c|c|c|c|}
\hline & 2007 & 2008 & 2009 & 2010 & 2011 & 2012 & 2013 & 2014 & 2015 & 2016 & 2017 & 2018 \\
\hline$U B U$ & 692 & 688 & 694 & 692 & 747 & 762 & 733 & 751 & 777 & 776 & 803 & 819 \\
\hline ULE & 955 & 950 & 987 & 952 & 920 & 942 & 908 & 854 & 883 & 900 & 925 & 942 \\
\hline USAL & 2,374 & 2,658 & 2,709 & 2,481 & 2,469 & 2,425 & 2,334 & 2,306 & 2,312 & 2,301 & 2,272 & 2,317 \\
\hline UVA & 2,519 & 2,519 & 2,497 & 2,645 & 2,590 & 2,473 & 2,029 & 2,199 & 2,260 & 2319 & 2,314 & 2,286 \\
\hline
\end{tabular}

Regarding the information on the academic communities of the four universities under analysis, the data of the used academic years are from 2006-2007 to 2017-2018. Since the data is collected by academic years, the annual occurrence set out in Tables 1, 2 and 3 has been fixed according to the last year of the corresponding academic year.

Regarding the number of students at each institution, the figures of first cycle (diplomatura or diploma), second cycle (licenciatura or bachelor's degree), and master's degree were taken into account for the years 2007-2008. For the rest of the period studied (2009-2018), bachelor's and master's degrees figures were used, once these new degrees were implemented in the 2009-2010 academic year, in accordance with the guidelines of the European Higher Education Area (EHEA). These data are shown in Table 2, which have been taken from Excel files available on the EducaBase statistics platform.

http://estadisticas.mecd.gob.es/EducaDynPx/educabase/index.htm?type=pcaxis\&path=/Universitaria/Series/ Estudiantes/Matriculados

The parallelism in size of USAL and UVA, and the proximity between UBU and ULE, are clearly observed, although in the latter case more in number of faculty than students.

Table 2. Students of the public universities of Castile and Leon

\begin{tabular}{|l|c|c|c|c|c|c|c|c|c|c|c|c|}
\cline { 2 - 13 } \multicolumn{1}{c|}{} & $\mathbf{2 0 0 7}$ & $\mathbf{2 0 0 8}$ & $\mathbf{2 0 0 9}$ & $\mathbf{2 0 1 0}$ & $\mathbf{2 0 1 1}$ & $\mathbf{2 0 1 2}$ & $\mathbf{2 0 1 3}$ & $\mathbf{2 0 1 4}$ & $\mathbf{2 0 1 5}$ & $\mathbf{2 0 1 6}$ & $\mathbf{2 0 1 7}$ & $\mathbf{2 0 1 8}$ \\
\hline UBU & 8,139 & 8,061 & 7,894 & 8,504 & 8,609 & 8,909 & 8,524 & 8,281 & 7,618 & 7,093 & 7,014 & 7,002 \\
\hline ULE & 13,912 & 12,158 & 11,874 & 11,808 & 13,076 & 14,703 & 14,954 & 14,362 & 13,559 & 11,650 & 10,761 & 10,334 \\
\hline USAL & 26,503 & 26,414 & 26,135 & 26,221 & 26,217 & 27,966 & 27,231 & 26,137 & 24,368 & 22,980 & 22,901 & 22,869 \\
\hline UVA & 26.515 & 26.028 & 25.218 & 24.908 & 24.772 & 25.357 & 24.996 & 25.734 & 23.917 & 21.701 & 21.122 & 20.351 \\
\hline
\end{tabular}

In the EducaBase database the data of students enrolled in doctoral studies were not offered until the 2014-2015 academic year, and considering that it is a relevant fact, since these students in principle would be the ones that make the most use of electronic journals, the doctoral theses defended in each of the universities analyzed were drawn from the Teseo database as an approximation to the number of doctoral students.

https://www.educacion.gob.es/teseo

It should be noted that that the consumption of information by doctoral students not only occurs in the year of defending, but it is considered that this year and the amount of thesis can be indicative data on the potential use of this type of users. As can be seen in Table 3, there was a gradual, although not constant, increase in the number of theses defended until the 2015-2016 academic year. In that year this number multiplied, largely due to the expiration of the due date for the students enrolled in the doctorate following the old curriculum, in order to defend their thesis. Furthermore, there was a decrease in the last two years analyzed at the four universities in the study.

Table 3. Number of theses read in the public universities of Castile and Leon

\begin{tabular}{|c|c|c|c|c|c|c|c|c|c|c|c|c|}
\hline & 2007 & 2008 & 2009 & 2010 & 2011 & 2012 & 2013 & 2014 & 2015 & 2016 & 2017 & 2018 \\
\hline$U B U$ & 27 & 25 & 30 & 37 & 38 & 29 & 33 & 41 & 54 & 126 & 15 & 2 \\
\hline ULE & 79 & 67 & 61 & 109 & 96 & 92 & 94 & 81 & 85 & 243 & 105 & 42 \\
\hline USAL & 220 & 243 & 242 & 222 & 255 & 290 & 274 & 292 & 318 & 614 & 367 & 264 \\
\hline UVA & 87 & 124 & 126 & 133 & 135 & 195 & 201 & 203 & 215 & 451 & 166 & 110 \\
\hline
\end{tabular}

The four providers analyzed were contracted by the Bucle consortium at the beginning of the 2000s and their content was analyzed to better understand the depth of the materials (Rodríguez-Bravo; Alvite-Díez, 2004; 2005). Over the studied years, the number of journals provided increased, largely due to mergers and the acquisitions of other publishers. ScienceDirect, produced by Elsevier, just like the big deals of Springer and Wiley publishers, are multidisciplinary electronic content bundles, supplying more than 2,000 electronic journals. Emerald is a distributor that specializes in social sciences with a smaller number of journals, close to 500 .

\section{Results}

The results are presented in two sections. In the first one, the volume of downloads of articles from the journals included in the big deals subscribed to by the consortium of university libraries of Castile and Leon is analyzed. In the second 
one, the distribution of the use of the subscribed titles of the four analyzed providers is studied: Emerald, ScienceDirect, Springer, and Wiley.

\subsection{Downloads of articles from the contracted journals}

In this section we analyze, in aggregate, the downloads of articles at the four public universities of Castile and Leon during the 12 years included in the study: those attributable to each of these universities, annual downloads by university and by provider, and the relationship between downloads and university size.

Graph 1 shows the evolution of the total journal article downloads between 2007 and 2018, as well as the annual growth rate. First of all, it is essential to point out the continued and significant increase of downloads over the twelve-year period analyzed. The number of downloads between 2007 and 2018 has doubled and data from recent years suggest that the growth trend continues. The year-to-year growth rate has been positive during the last 6 years and in 2018 it reached $13.29 \%$.

\subsubsection{Total annual downloads by uni- versity}

If we take into account the evolution

of downloads by universities (Graph 2), a tendency toward an increase of downloads in the twelve studied years is confirmed. However, there is a discordant element, as a break in that evolution can be observed. In 2009 there was a significant decrease (growth rate of -5.57\%) attributed to Universidad de León (75,223 downloads in 2009 versus 126,107 in 2008) and to Universidad de Salamanca (137,504 in 2009 compared to 138,162 in 2008). In 2012 we identified another decrease, less important than the one described above (growth rate of $-0.45 \%$ ), which can also be attributed to the downloads made at the Universidad de León (101,287 in 2012 versus 114,152 in 2011) and the Universidad de Valladolid (178,430 in 2012 compared to 194,992 in 2011).

In absolute terms, the largest universities, Salamanca and Valladolid, made the most of their big deal subscriptions. The Universidad de Burgos, with a smaller academic community, had a lower number of downloads while the Universidad de León was in an intermediate position, reflecting its size.

In relative terms, the Universidad de Burgos is where the increase in downloads was the most significant, they nearly tripled. The Universidad de Valladolid that had the highest download figures in the first few years studied, from 2010 has experienced a more moderate growth than the one of the Universidad de Salamanca, and has not been able to duplicate the number of downloads as it happened at the universities of León and Salamanca.

Only at the Universidad de Burgos was the increase constant and consistent. At the other universities there were occasional decreases, in 2009 -in León and Salamanca-, in 2012 -in León and Valladolid-, in 2016 -in Valladolid- and in 2017 -in Salamanca-.

\subsubsection{Annual downloads by provider}

As seen in Graph 3 [and as it had been observed in other works related to this geographical area (Rodríguez-Bravo; Alvite-Díez, 2006a; 2011; Rodríguez-Bravo et al., 2008) and also numerous studies in other environments have corroborated, such as those in the United Kingdom and France (Ciber, 2009; Boukacem-Zeghmouri;
The number of downloads between 2007 and 2018 doubled, and data from recent years suggests that the growth trend continues 
Schöpfel, 2008)] ScienceDirect, an electronic information bundle of Elsevier, is the provider that distributes the journals of priority use by academics and accounts for $75.34 \%$ of the overall downloads, 5.6 times Wiley's downloads, 7.4 Springer's downloads, and more than 70 times Emerald's downloads.
ScienceDirect, from Elsevier, accounts for $75.34 \%$ of the overall downloads, 5.6 times those of Wiley's, 7.4 times Springer's, and more than 70 times Emerald's

In line with its smaller size, the number of Emerald's downloads is low, as can be seen in Graph 3. Moderate global figures are observed in all years, but they increase steadily from 2015, exceeding 10,000 downloads for all the universities for the first time in 2018. The total downloads of Emerald in the analyzed period is close to $80,000(79,697)$, but accounts for $1.04 \%$ of the total (Table 4).

In Springer and Wiley we also observe an increase in the downloads, although with some oscillations. It should be noted that there was an increase of Wiley use starting in 2010, with some occasional moderate recoils. The global downloads of this provider at the four universities exceeds one million $(1,025,537)$, which represents $13.4 \%$ of the total (Table 4). In the case of Springer, there was a significant increase in 2011, a subsequent decrease until 2015 and a determined growth since then. Statistics show us that the joint downloads reached $781,518(10.21 \%)$ during the period.

If we consider the evolution of the global data of these two providers, during the first three years the use of the journals of both distributors is similar, although slightly bigger for Springer. From 2010, however, Wiley's downloads are significantly higher than those of Springer.

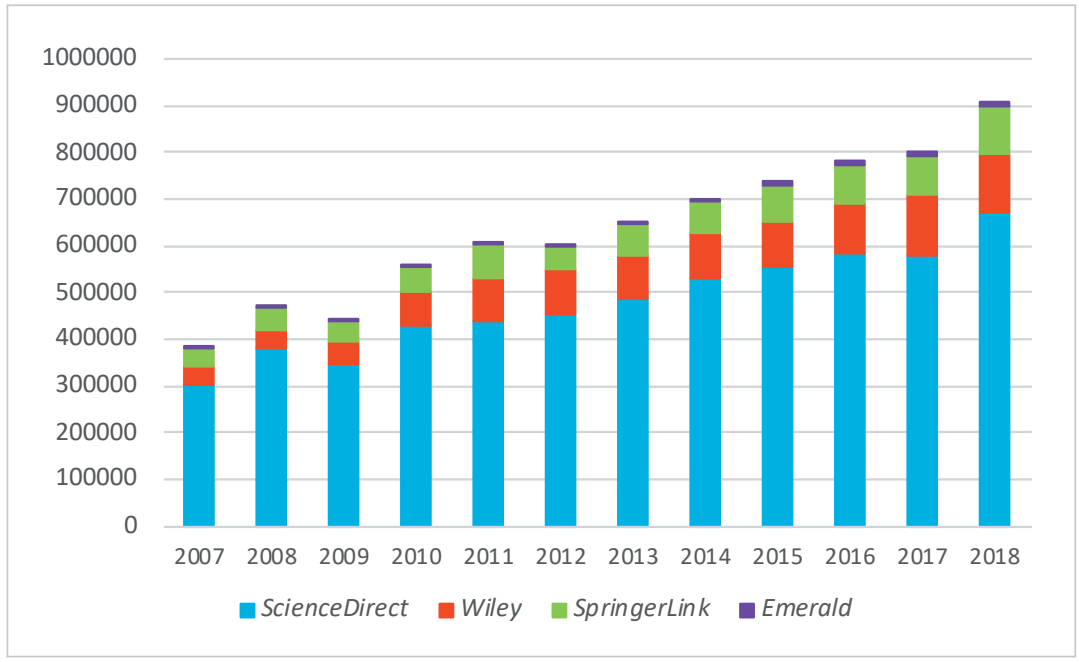

Graph 3. Downloads by provider

Table 4. Global number of downloads by university and provider

\begin{tabular}{|l|c|c|c|c|}
\cline { 2 - 5 } \multicolumn{1}{c|}{} & ScienceDirect & Springer & Wiley & Emerald \\
\hline UBU & 793,308 & 81,624 & 141,806 & 17,259 \\
\hline ULE & $1,138,825$ & 153,644 & 171,980 & 11,998 \\
\hline USAL & $2,008,016$ & 317,313 & 432,810 & 32,268 \\
\hline UVA & $1,824,785$ & 228,937 & 278,941 & $1,476,447$ \\
\hline Total & $5,764,934$ & 781,518 & $1,025,537$ & 79,172 \\
\hline
\end{tabular}

We can qualify the individualized preferences of universities shown in Table 4. The use distribution of the journals of the four analyzed suppliers is similar across the four universities. ScienceDirect is the most used provider, with $77.62 \%$ of the downloads occurring at the Universidad de Valladolid, $77.24 \%$ at León, 76.72\% at Burgos and $71.96 \%$ at Salamanca. It is followed by Wiley and Springer, in this order, at all the universities, although the difference between both providers varies between some universities. Thus, in the case of Burgos, Wiley accounts for $13.7 \%$ of downloads and Springer $7.9 \%$, while in León or Valladolid the differences do not reach $3 \%$ (11.6\% vs. $10.4 \%$ in León and $11.9 \%$ vs. 9.7\% in Valladolid). Emerald is the least used provider with values around $1 \%$ of the downloads, although the case of the Universidad de Burgos is noteworthy, with $1.67 \%$ of downloads. In absolute terms, Emerald use at Universidad de Burgos surpasses Universidad de Leon and practically equals the use at Universidad de Valladolid, despite being a smaller university with fewer total downloads. This greater use in Burgos could be due to a noted presence of Social Sciences degrees in this university (41.5\%), which is the thematic area in which Emerald specializes.

\subsubsection{Relationship between downloads and university volume}

If we observe the relationship of the downloads in relation to the main users of the electronic journals, the researchers, the increase is observed again in absolute terms, noting that the number of downloads per researcher has clearly doubled in the analyzed period (Graph 4). There was an increase from an average of 59.3 downloads per researcher in 2007 to 143 in 2018. Starting in 2013, when observing the average, the download/faculty ratios exceed one hundred, with the exception of the Universidad de Valladolid where these figures were not reached until 2018. 
It has been verified that the Universidad de León had the most intense use of the big deals studied, above the Universidad de Burgos, in all years except 2009, a year in which we already noted there was an anomalous decrease in downloads. Universidad de Burgos was also above the average throughout the studied period. However, the situation at the Universidad de Salamanca and Valladolid was reverse. Salamanca exceeded the average in 2012, 2016, 2017 and 2018 and Valladolid only in 2009, the year in which the average dropped due to the sharp decrease in downloads at the Universidad de León.

When comparing the data of the four universities, it was observed that universities with more faculty had more downloads, causing a positive correlation between the volume of downloads and the number of faculty $(r=0.77)$. However, as can be seen in Graph 5, there were notable differences in the volume of downloads between Salamanca and Valladolid and between León and Burgos, although these universities have a fairly similar amount of personnel. As can be seen in Graph 4 , the number of downloads per researcher varied significantly between universities. In fact, when we analyzed the data longitudinally, we saw that the volume of downloads followed an ascending line while the faculty number was still or even decreased. This time analysis shows a paradoxical negative correlation between downloads and number of faculty when analyzing in aggregate form the overall data of the four universities $(r=-0.64)$, which occurred when analyzing longitudinally and individually the universities of León $(r=-0.51)$, Salamanca $(r=-0.78)$ and Valladolid $(r=-0.54)$. This paradox did not happen in the case of Burgos $(r=0.93)$, whose workforce was the only one that grew in the analyzed period. This leads us to think that the number of faculty largely determines the volume of downloads. However, considering the universities in isolation, the progressive growth of the use of scientific journals over time would not only be related to faculty numbers, but aspects such as:

- evolution of the behavior patterns of the different academic communities;

- major scientific areas in these institutions;

- preference for other journal providers not analyzed in this work.

Regarding the relationship between downloads and students, the situation is similar: the number of students decreases over the period of time studied, while downloads increase. Although we do not have differentiated data on researchers and student downloads, because Counter (JR1) reports does not provide this information, it is probably that these students, especially those of the first cycles, resort more frequently to consulting manuals rather than the specialized research found in journal articles. This situation was verified in a study (Rodríguez-Bravo et al., 2015) that analyzed the bibliographies of the subjects of 11 degrees at three universities, including those of León and Salamanca, through their guides/teaching records of the academic year 2013-2014. The study found that books were the dominant resources for students. The percentage of articles from electronic journals in the bibliographies of the syllabi was still small and did not exceed $5 \%$.

In relation to doctorate students, there is a certain correlation between the number of defended thesis and downloads, although not a very strong one both at the aggregate level $(r=0.42)$ and at the individual level in each university $(r=$ 0.56 in Salamanca and $r<0.4$ in other universities). The increase in downloads has been constant since 2012, with its maximum in 2018, while the defense of theses have not had such a sustained growth, reaching its maximum in 2016 and decreasing notably in the last two years, just when the number of downloads was the highest. 


\subsection{Journal titles used}

This section examines the specific use of the subscribed collections based on the data of titles used in the bundles studied, as well as the representativeness in terms of downloads of the preferred titles within the total of the subscribed and used ones. The analysis is limited to the 2010-2018 period, as these are the years for which complete data on the downloads of each title are available from the four universities.

\subsubsection{Annual evolution of subscribed / used titles}

As can be seen in Table 5, there are oscillations in the number of titles subscribed to year-by-year. There are also differences between the institutions analyzed, because the universities of Castile and Leon formalize the subscriptions individually, although they negotiate as a consortium. We understand that the core collection is the same, although the universities may optionally include additional titles which can depend on the paper subscriptions they had or still have with the publisher.

Table 5. Titles subscribed to and used per university

\begin{tabular}{|c|c|c|c|c|c|c|c|c|c|c|c|}
\hline & & & & & & & & & & & \\
\hline & & 2009 & 2010 & 2011 & 2012 & 2013 & 2014 & 2015 & 2016 & 2017 & 2018 \\
\hline \multirow{2}{*}{$U B U$} & Subscribed & 8,255 & 8,232 & 7,650 & 8,024 & 8,343 & 8,548 & 8,814 & 9,090 & 8,120 & 8,228 \\
\hline & Used & 2,522 & 3,020 & 3,050 & 3,138 & 3,252 & 3,448 & 3,697 & 3,951 & 4,149 & 4,471 \\
\hline \multirow{2}{*}{ ULE } & Subscribed & 6,756 & 8,082 & 8,101 & 8,310 & 8,651 & 7,859 & 8,633 & 9,365 & 8,251 & 8,413 \\
\hline & Used & 2,741 & 3,648 & 4,006 & 3,230 & 2,397 & 4,008 & 4,717 & 5,036 & 5,108 & 5,474 \\
\hline \multirow{2}{*}{ USAL } & Subscribed & 8,265 & 7,543 & 7,727 & 8,053 & 8,397 & 8,719 & 9,057 & 9,380 & 8,392 & 8,518 \\
\hline & Used & 4,366 & 5,036 & 5,160 & 5,127 & 5,138 & 5,232 & 5,865 & 6,330 & 6,373 & 6,664 \\
\hline \multirow{2}{*}{ UVA } & Subscribed & 5,854 & 7,284 & 7,964 & 8,532 & 8,688 & 8,904 & 9,111 & 9,317 & 8,050 & 8,100 \\
\hline & Used & 3,737 & 4,389 & 4,749 & 4,689 & 4,655 & 4,839 & 5,453 & 5,546 & 5,741 & 6,060 \\
\hline
\end{tabular}

In Graph 6 we observe that the number of titles used was around $50 \%$ of the number of subscribed ones during the first few years analyzed, and exceeds $65 \%$ in the last two. Thus, the tendency to increase downloads -at a general level-was also observed in a trend towards greater dispersion and flexibility in the use of journals.

When analyzing the data of each university, it can be seen that the percentage of titles downloaded is closely related to the size of the universities, in the same way the volume of the downloads was. The Universidad de Salamanca exceeded $60 \%$ of the use of the subscribed titles every year, and reached $78 \%$ in 2018, while the Universidad de Valladolid used between $50 \%$ and $75 \%$. However, the percentages of use in León and Burgos, the smallest universities, were notably lower, with values between $36 \%$ and $54 \%$ in the case of Burgos and with pronounced oscillations in the Universidad de León with values between $27 \%$ and $65 \%$. In any case, an increase in the percentage of titles used throughout the period

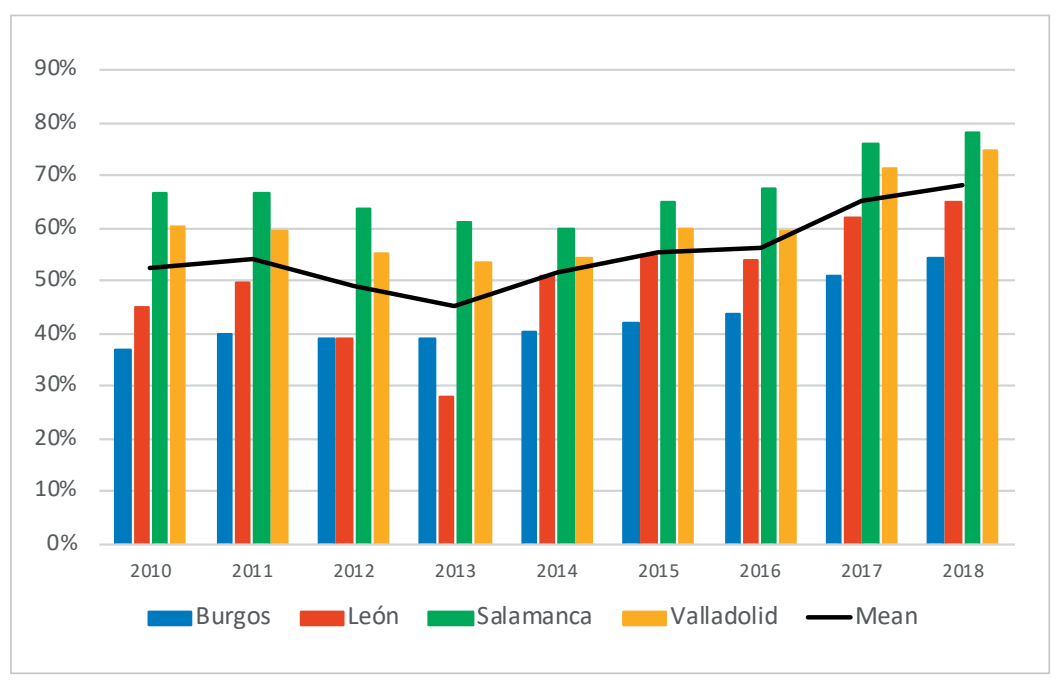

Graph 6. Percentage of titles used per university studied was observed, especially after 2013.

If we look at the evolution of the titles used by provider (Graph 7), only ScienceDirect offers journals that are mostly of interest to the universities under study, with usage percentages ranging between $67 \%$ and $79 \%$ of the subscribed titles. In the case of the remaining providers, the titles that received downloads did not reach $50 \%$ of the bundles subscribed to in most of the analyzed period. However, there was an increase in the dispersion of the use of the Emerald and Springer bundles in the last few years studied, especially after 2015 in the case of Emerald and after 2016 in a more pronounced way for Springer.

As indicated in the methodology, the number of Emerald and Springer total subscriptions after 2017 were not listed in the download reports that providers offered to libraries. Consequently, these data were presented to us by the acquisition managers in the studied libraries, who requested them from the providers. Perhaps this circumstance has influenced the increase of used titles that we observed in last few years. 


\subsubsection{Representativeness of preferred titles in total downloads}

Three of the big deals analyzed (ScienceDirect, Springer, and Wiley) exceeded 2,000 titles each and 25 of those titles represented between $10 \%$ and more than $30 \%$ of total downloads. This finding implies a considerable concentration of use, as shown in Graph 8.

The highest concentration occurs in the smallest university, the Universidad de Burgos, and the lowest concentration in one of the two large universities, the Universidad de Salamanca, which was also the one that made the most intense use of the electronic information included in these big deals. Logically, the greater the diversity of knowledge areas of the universities, the more possibilities there are for the range of titles used to increase.

3.2.3. Representativity of $50 \%$ of downloads over all the titles used and titles subscribed in each university

The percentage of titles used that satisfy half of the demand for information at the studied universities (Graph 9) clearly demonstrates the concentration of use in a certain number of titles, which tended to be very reputable titles, as found in previous studies (Rodríguez-Bravo; Alvite-Díez, 2006a; 2006b; Rodríguez-Bravo; Alvite-Díez; Barrionuevo-Almuzara, 2012). With less than $6 \%$ of the titles used, $50 \%$ of the demands would be satisfied.

It is known that the needs of scientists focus on the lines of research that they are currently developing. Hence, when there are more researchers and greater diversity among scientific areas of research, the more titles that will be used.

As can be seen in Graph 9, the universities of Salamanca and León had a larger variety in title use. The Universidad de Salamanca made a better cost-benefit rate from the subscriptions to the big deals as we already established with the data of global downloads. The Universidad de Burgos, smaller and with faculty from a limited range of research areas -because the number of degrees they offer is lower-, showed that less than $3 \%$ of their journal titles satisfied more than $50 \%$ of their information needs. Universidad de León showed the most irregular behavior with an unusual dispersion in 2013.

When we consider the journal subscriptions from which $50 \%$ of the downloads were derived (Graph 10), we can see that, in the case of the Universidad de Burgos, $50 \%$ of downloads corresponded to approximately $1 \%$ of the subscription titles, showing a uniform line without variation in the 2010-2015 period. 
The Universidad de León showed a fluctuation between a percentage of 1.72 in 2012 and 2.63 in 2014. The universities of Salamanca and Valladolid showed higher percentages, but also uniformity. Salamanca moved around $3.37 \%$ and $3.91 \%$ for the lowest and highest percentage, and Valladolid between $2.08 \%$ and $2.79 \%$.

It is the large universities, with larger academic communities and different sectors of research, who can made better use of the wide range of content offered by the big deals negotiated by Bucle consortium. The data obtained, which may represent the situation in other regions, puts into question the current electronic content purchase system through multidisciplinary big deals.

\section{Conclusions and final discussion}

In this study we analyzed the downloads in the public universities of the Castile and Leon region (Spain) of journal articles of four big deals of the publishers Elsevier, Emerald, Springer, and Wiley, which were subscribed to at the beginning of the $21^{\text {st }}$ century and continue to today. Downloaded data, which we consider indicators of the use that universities make of electronic journals, show how, from 2007 to 2018, article downloads increased gradually and even increased decidedly in 2018. This situation occurred despite

- the fact that the number of faculty and students decreased during the interval studied,

- easier access to available content through WorldCat Discovery, and

- the proliferation of open access journals, repositories, and platforms such as Sci-Hub, which are generating new forms of access to scientific information and that are increasingly important in the academic community (Himmelstein et al., 2018; González-Solar; Fernández-Marcial, 2019; Nicholas et al., 2019).

Although it is difficult to give an explanation or hypothesis that explains this increase in downloads, we believe the need to access scientific articles has increased in recent years because the pressure to publish has increased in Spain. Academics are constantly subjected to accreditation and evaluation processes, and universities are interested in positioning themselves in international rankings, which place high value on scientific production. Likewise, new curricula that includes end-of-degree or master's degree final projects have produced an increase of the use of subscribed resources in Spain. The increase in the number of doctorate theses defended before 2016 may has also contributed to the greater number of downloads, although the data from the last two years does not back up this hypothesis.

As expected, the results show that the number of downloads was closely related to the size of the universities, and the total number of downloads was much higher at the universities of Valladolid and Salamanca when compared to León and Burgos. However, when we observed the data that related downloads to the number of faculty, we verified a larger relative use by researchers from smaller universities. Although larger universities, with more users and greater diversity of research areas, such as Salamanca and Valladolid, were more likely to make big deals with a better cost-benefit ratio than the small ones, the results did not show that the differences in the percentages of titles used are very important. The greater benefit of subscriptions by large universities is best seen in the concentration of downloads, where the differences are most notable.

The electronic content provider Elsevier-ScienceDirect enjoys the most use in the four universities analyzed, with downloads exceeding those of the three remaining providers together. The volume of content and thematic coverage is not a reason for this consolidated preference, given that Wiley and Springer products are also multidisciplinary, and the universities of Castile and Leon have signed a fairly similar amount of titles with the three providers. We believe that the reason must be related to the quality of the distributed content, a subject already addressed in the bibliography (Rodríguez-Bravo; Alvite-Díez; Barrionuevo-Almuzara, 2012), but which should be investigated in the future.
Large universities, with larger academic communities and different sectors of knowledge, can make better use of the wide range of content offered by big deals 
The other, most important finding of this research, in line with those obtained in other previous studies (Rodríguez-Bravo; Alvite-Díez, 2006a; 2011; Rodríguez-Bravo et al., 2008), is that the universities analyzed used a limited number of titles from the bundle subscriptions and that a few journals agglutinate most of the downloads. Although a priori the demand for information is flexible, the downloads were concentrated from a limited number of reputed titles. Therefore, many of the titles sold by providers attract little or no use at all. This is one of the main arguments that has been used to question the big deal model, because it does not seem worthwhile to hire clone collections in all universities regardless of the volume of staff, the degrees they teach, and the areas of knowledge that they constitute. Libraries and universities have repeatedly advocated for the possibility of an offer tailored to the needs of each institution (Icolc, 2010).

We believe that the big deal has been a convenient model for libraries that, with a shortage of staff to dedicate to usage evaluations, have chosen to keep subscriptions despite their limited use, even in times of crisis such as the one Spain and other countries have experienced during the period studied. However, at present we believe it is necessary to question the sustainability of the model. Not only because subscription prices continue to rise and a large number of resources are underutilized, but also because we are in a new context marked by the advance of the open access movement, the use of platforms such as Sci-Hub or ResearchGate, and other emerging possibilities for accessing scientific information.

In this context, a post big deal era is beginning in which access to content through intermediary platforms -document delivery- or through interlibrary loans is filling information needs. Likewise, other models such as Publish \& Read (P\&R) / Read \& Publish (R\&P) are emerging. It is worth mentioning some agreements that help to explore new routes and models in the provision of content, for example:

- Wiley \& ProjektDeal, in Germany;

- Massachusetts Institute of Technology (MIT) \& Royal Society of Chemistry, in the EUA;

- pilot project of Springer Nature \& ResearchGate (March-June 2019).

In our study we have not noticed that the big deal model shows signs of decline in Castile and Leon, but we do believe that the application of the Plan S guidelines to promote open science from 2021 could mark a moment of critical inflection.

In this work, the first results have been presented, mainly descriptive, of a broader investigation that seeks to deepen the knowledge of the use and profitability of the investment in electronic journals through the subscriptions of the four libraries of the public universities in Castile and Leon. This first approach offers a series of global data on downloads, which show an overview of their evolution and their focus in a limited number of titles. As future lines of work already underway, it is intended to deepen the profitability of subscriptions in terms of cost-use and impact on the scientific production of users of these universities. The analysis of the scientific production and of the referen-

We believe it is necessary to question the sustainability of the big deal model

ces used in the mentioned production will allow us to find out, first-hand, the actual uses and benefits of the journals subscribed, as well as to see to what extent a greater number of downloads may be related to greater production. Additionally, this information will be analyzed individually for the different areas and scientific disciplines, since the use of the journals can depend on the thematic profile of the users and their behavior when searching and using information.

\section{References}

Anderson, Chris (2006). The long tail: Why the future of business is selling less of more. New York: Hyperion Books. ISBN: 978140130237 http://dl.motamem.org/long_tail_chris_anderson_motamem_org.pdf

Armstrong, Kimberly L.; Teper, Thomas H. (2017). "Library consortia and the CIC: Leveraging scale for collaborative success". Serials review, v. 43, n. 1, pp. 28-33.

https://doi.org/10.1080/00987913.2017.1284493

Arthur, Michael A. (2018). "Managing a comprehensive cost-per-use project in a large academic library". Serials review, v. 44, n. 4, pp. 299-306.

https://doi.org/10.1080/00987913.2018.1558936

Belter, Cristopher W.; Kaske, Neal K. (2016). "Using bibliometrics to demonstrate the value of library journal collections". College and research libraries, v. 77, n. 4, pp. 410-422.

https://doi.org/10.5860/CRL.77.4.410

Bergstrom, Theodore C.; Courant, Paul N.; McAfee, Preston R.; Williams, Michael A. (2014). "Evaluating big deal journal bundles". Proceedings of the National Academy of Sciences of the United States of America, v. 111, n. 26, pp. 9425-9430. https://doi.org/10.1073/pnas.1403006111 
Blecic, Deborah D.; Wiberley, Stephen E.; Fiscella, Joan B.; Bahnmaier-Blaszczak, Sara; Lowery, Rebeca (2013). “Deal or no deal? Evaluating big deals and their journals". College \& research libraries, v. 74, n. 2, pp. 178-193.

https://doi.org/10.5860/crl-300

Boots, Angela; Chester, Julia; Shaw, Emma; Wilson, Chris (2007). "E-journal usage statistics in action: A case study from cancer research UK". In: Fowler, David C. (ed.). Usage statistics of e-serials. New York: Haworth Information Press, pp. 183-198. ISBN: 9780789029881

Borrego, Ángel; Anglada, Lluís (2016). "Faculty information behaviour in the electronic environment". New library world, v. 117, n. 3/4, pp. 173-185.

https://doi.org/10.1108/NLW-11-2015-0089

Boukacem-Zeghmouri, Chérifa; Bador, Pascal; Lafouge, Thierry; Prost, Hélène (2016). "Relationships between consumption, publication and impact in French universities in a value perspective: A bibliometric analysis". Scientometrics, v. 106, n. 1 , pp. $263-280$.

https://doi.org/10.1007/s11192-015-1779-z

Boukacem-Zeghmouri, Chérifa; Schöpfel, Joachim (2008). “On the usage of e-journals in French universities”. Serials, v. 21, n. 2, pp. 121-126.

https://doi.org/10.1629/21121

Britten, William A. (1990). "A use statistic for collection management: The 80/20 rule revisited". Library acquisitions: Practice and theory, v. 14, n. 2, pp. 183-189.

https://doi.org/10.1016/0364-6408(90)90061-X

Bucknall, Tim; Bernhardt, Beth; Johnson, Amanda (2014). "Using cost per use to assess big deals". Serials review, v. 40, n. 3, pp. 194-196.

https://doi.org/10.1080/00987913.2014.949398

Chew, Katherine; Schoenborn, Mary; Stemper, James; Lilyard, Caroline (2016). "E-journal metrics for collection management: Exploring disciplinary usage differences in Scopus and Web of Science". Evidence based library and information practice, v. 11, n. 2, pp. 97-120.

https://doi.org/10.18438/B85P87

Ciber (2009). E-Journals: their use, value and impact. Centre for Information Behaviour and the Evaluation of Research. London: City University.

http://www.rin.ac.uk/system/files/attachments/E-journals-report.pdf

Coughlin, Daniel M.; Campbell, Mark C.; Jansen, Bernard J. (2016). “A web analytics approach for appraising electronic resources in academic libraries". Journal of the Association for Information Science and Technology, v. 67, n. 3, pp. 518534.

https://doi.org/10.1002/asi.23407

Dempsey, Lorcan (2006). "Libraries and the long tail. Some thoughts about libraries in a network age". D-lib magazine, v. 12 , n. 4.

https://doi.org/10.1045/april2006-dempsey

Dempsey, Lorcan; Malpas, Constance; Lavoie, Brian (2014). "Collection directions: The evolution of library collections and collecting". Portal: Libraries and the academy, v. 14, n. 3, pp. 393-423.

https://doi.org/10.1353/pla.2014.0013

Duan, Yufeng; Xiong, Zequan (2017). "Download patterns of journal papers and their influencing factors". Scientometrics, v. 112, n. 3, pp. 1761-1775.

https://doi.org/10.1007/s11192-017-2456-1

Emrani, Ebrahim; Moradi-Salari, Amin; Jamali, Hamid R. (2010). “Usage data, e-journal selection, and negotiations: An Iranian consortium experience". Serials review, v. 36, n. 2, pp. 86-92.

https://doi.org/10.1080/00987913.2010.10765289

Frazier, Kenneth (2005). "What's the big deal?". The serials librarian, v. 48, n. 1-2, pp. 49-59. https://doi.org/10.1300/J123v48n01_06

González-Solar, Llarina; Fernández-Marcial, Viviana (2019). "Sci-Hub, a challenge for academic and research libraries". El profesional de la información, v. 28, n. 1, e280112.

https://doi.org/10.3145/epi.2019.ene.12

Gorraiz, Juan; Gumpenberger, Christian; Schlögl, Christian (2014). “Usage versus citation behaviours in four subject areas". Scientometrics, v. 101, n. 2, pp. 1077-1095.

https://doi.org/10.1007/s11192-014-1271-1 
Himmelstein, Daniel S.; Rodríguez-Romero, Ariel; Levernier, Jacob G.; Munro, Thomas-Anthony; McLaughlin, StephenReid; Tzovaras, Bastian-Greshake; Greene, Casey S. (2018). "Sci-Hub provides access to nearly all scholarly literature". elife, v. 1, n. 7, pii: e32822.

https://doi.org/10.7554/eLife.32822

Icolc (2010). Statement on the global economic crisis and its impact on consortial licenses. International Coalition of Library Consortia.

http://icolc.net/statement/revised-statement-global-economic-crisis-and-its-impact-consortial-licenses

Jamali, Hamid R.; Nabavi, Majid (2015). "Open access and sources of full-text articles in Google Scholar in different subject fields". Scientometrics, v. 105, n. 3, pp. 1635-1651.

https://doi.org/10.1007/s11192-015-1642-2

Jung, Youngim; Kim, Jayhoon; So, Minho; Kim, Hwanmin (2015). "Statistical relationships between journal use and research output at academic institutions in South Korea". Scientometrics, v. 103, n. 3, pp. 751-777.

https://doi.org/10.1007/s11192-015-1563-0

Kostagiolas, Petros A.; Korfiatis, Nikolaos; Poulos, Marios (2012). "A long-tail inspired measure to assess resource use in information services". Library \& information science research, v. 34, n. 4, pp. 317-323.

https://doi.org/10.1016/j.lisr.2012.05.002

Kwon, Diana (2018). "French universities cancel subscriptions to Springer journals". The scientist, March 31. https://www.the-scientist.com/daily-news/french-universities-cancel-subscriptions-to-springer-journals-29882

Martin, Virginia; Gray, Teddy; Kilb, Megan; Minchew, Tessa (2016). “Analyzing consortial 'big deals' via a cost-per-cited-reference (CPCR) metric". Serials review, v. 42, n. 4, pp. 293-305.

https://doi.org/10.1080/00987913.2016.1248218

McDonald, John D. (2007). "Understanding journal usage: A statistical analysis of citation and use". Journal of the American Society for Information Science and Technology, v. 58, n. 1, pp. 39-50.

https://doi.org/10.1002/asi.20420

Meier, Andreas; Tunger, Dirk (2018). "Survey on opinions and usage patterns for the ResearchGate platform". Plos one, v. 13, n. 10, e0204945.

https://doi.org/10.1371/journal.pone.0204945

Nicholas, David; Boukacem-Zeghmouri, Chérifa; Rodríguez-Bravo, Blanca; Xu, Jie; Watkinson, Anthony; Abrizah, Abdullah; Herman, Eti; Świgoń, Marzena (2017). "Where and how early career researchers find scholarly information". Learned publishing, v. 30, n. 1, pp. 19-29.

https://doi.org/10.1002/leap.1087

Nicholas, David; Boukacem-Zeghmouri, Chérifa; Xu, Jie; Herman, Eti; Clark, David; Abrizah, Abdullah; Rodríguez-Bravo, Blanca; Świgoń, Marzena (2019). "Sci-Hub: The new and ultimate disruptor? View from the front". Learned publishing, v. 32, n. 2, pp. 147-153.

https://doi.org/10.1002/leap.1206

Nisonger, Thomas E. (2008). "The 80/20 rule and core journals". Serials librarian, v. 55, n. 1-2, pp. 62-84. https://doi.org/10.1080/03615260801970774

Rafi, Muhammad; JianMing, Zheng; Ahmad, Khurshid (2019). "Evaluating the impact of digital library database resources on the productivity of academic research". Information discovery and delivery, v. 47, n. 1, pp. 42-52.

https://doi.org/10.1108/IDD-07-2018-0025

Rodríguez-Bravo, Blanca; Alvite-Díez, María-Luisa (2004). "Análisis de los contenidos distribuidos por proveedores de publicaciones electrónicas". El profesional de la información, v. 13, n. 6, pp. 441-449.

http://www.elprofesionaldelainformacion.com/contenidos/2004/noviembre/4.pdf

Rodríguez-Bravo, Blanca; Alvite-Díez, María-Luisa (2005). "Survey of the providers of electronic publications holding contracts with Spanish university libraries". D-lib magazine, v. 11, n. 4, pp. 20-39.

http://www.dlib.org/dlib/april05/alvite/04alvite.html

Rodríguez-Bravo, Blanca; Alvite-Díez, María-Luisa (2006a). "The use of electronic journals in academic libraries in Castilla y León". In: Brophy, Peter; Craven, Jenny; Markland, Margaret (eds.). Libraries without walls 6: Evaluating the distributed delivery of library services. London: Facet Publishing, pp. 125-137. ISBN: 9781856045766

Rodríguez-Bravo, Blanca; Alvite-Díez, María-Luisa (2006b) “Uso de las revistas-e suministradas por Emerald en bibliotecas universitarias españolas (2002-2005)". El profesional de la información, v. 15, n. 6, pp. 464-472.

http://www.elprofesionaldelainformacion.com/contenidos/2006/noviembre/08.pdf 
Rodríguez-Bravo, Blanca; Alvite-Díez, María-Luisa (2011). "An analysis of the use of electronic journals in a Spanish academic context: Developments and profitability". Serials review, v. 37, n. 3, pp. 181-195.

https://doi.org/10.1016/j.serrev.2011.06.003

Rodríguez-Bravo, Blanca; Alvite-Díez, María-Luisa (2013). "Impact of the consumption of electronic contents on research productivity in the universities of Castile and Leon". Library collections, acquisitions, and technical services, v. 37 , n. 3-4, pp. 85-106.

https://doi.org/10.1016/J.LCATS.2013.09.007

Rodríguez-Bravo, Blanca; Alvite-Díez, María-Luisa; Barrionuevo-Almuzara, Leticia (2012). "Trends and models in the consumption of electronic contents. An analysis of the journals most widely used in Spanish universities". Journal of academic librarianship, v. 38, n. 2, pp. 42-59.

https://doi.org/10.1016/j.acalib.2011.11.007

Rodríguez-Bravo, Blanca; Alvite-Díez, María-Luisa; Barrionuevo-Almuzara, Leticia; Morán-Suárez, María-Antonia (2008). "Patterns of use of electronic journals in Spanish university libraries". Serials review, v. 34, n. 2, pp. $115-128$.

https://doi.org/10.1016/j.serrev.2008.01.002

Rodríguez-Bravo, Blanca; Alvite-Díez, María-Luisa; Morán-Suárez, María-Antonia; Marraud, Gerardo (2012). “Impacto de la contratación de colecciones de revistas electrónicas en la productividad de la Universidad de Vigo". El profesional de la información, v. 21, n. 6, pp. 585-594.

https://doi.org/10.3145/epi.2012.nov.05

Rodríguez-Bravo, Blanca; Pacios, Ana-Reyes; Vianello-Osti, Marina; Moro-Cavero, Manuela; De-la-Mano-González, Marta (2015). "Digital transition of teaching learning resources at Spanish universities". El profesional de la información, v. 24, n. 6, pp. 737-748.

https://doi.org/10.3145/epi.2015.nov.05

Schonfeld, Roger C. (2019). "Is the value of the big deal in decline?". The scholarly kitchen, March 7. https://scholarlykitchen.sspnet.org/2019/03/07/value-big-deal-leakage

Schöpfel, Joachim; Leduc, Claire (2012). "Big deal and long tail: e-journal usage and subscriptions”. Library review, v. 61, n. 7, pp. 497-510.

https://doi.org/10.1108/00242531211288245

Shu, Fei; Mongeon, Philippe; Haustein, Stefanie; Siler, Kyle; Alperin, Juan-Pablo; Larivière, Vincent (2018). "Is it such a big deal? On the cost of journal use in the digital era". College \& research libraries, v. 79, n. 6, pp. 785-798.

https://doi.org/10.5860/crl.79.6.785

Singson, Mangkholien; Hangsing, Paokholun (2015). "Implication of 80/20 rule in electronic journal usage of UGC-Infonet Consortia". The journal of academic librarianship, v. 41, n. 2, pp. 207-219.

https://doi.org/10.1016/j.acalib.2014.12.002

Srivastava, Bhawana; Kumar, Sanjeev (2018). "Usage and impact of Science Direct material science package in a material science library". Desidoc. Journal of library \& information technology, v. 38, n. 1, pp. 21-26.

https://www.researchgate.net/publication/322469533_Usage_and_Impact_of_Science_Direct_Material_Science_ Package_in_a_Material_Science_Library

https://doi.org/10.14429/djlit.38.1.12124

Stemper, James A.; Jaguszewski, Janice M. (2003). "Usage statistics for electronic journals". Collection management, v. 28 , n. 4, pp. 3-22.

https://doi.org/10.1300/J105v28n04_02

Tetteh, Evelin O. Apronti (2018). "Usage evaluation of electronic resources in academic and research libraries in Ghana". Global knowledge, memory and communication, v. 67, n. 4/5, pp. 316-331.

https://doi.org/10.1108/GKMC-11-2017-0097

Tripathi, Manorama; Kumar, Sunil (2014). "Use of online resources at Jawaharlal Nehru University: a quantitative study". Program, v. 48, n. 3, pp. 272-292.

https://doi.org/10.1108/PROG-11-2012-0059

Trueswell, Richard L. (1969). "Some behavioral patterns of library users: The 80/20 rule". Wilson library bulletin, v. 43, n. 5, pp. 458-461.

https://eric.ed.gov/?id=EJ005380

University of California (2019). "Negotiating with scholarly journal publishers: A toolkit from the University of California". Office of scholarly communication. May.

https://osc.universityofcalifornia.edu/open-access-at-uc/publisher-negotiations/negotiating-with-scholarly-journalpublishers-a-toolkit 
Urbano, Cristóbal; Anglada, Lluís M.; Borrego, Ángel; Cantos, Carme; Cosculluela, Antonio; Comellas, Núria (2004). "The use of consortially purchased electronic journals by the CBUC (2000-2003)". D-lib magazine, v. 10, n. 6.

http://www.dlib.org/dlib/june04/anglada/06anglada.html

Wang, Xianwen; Fang, Zhichao; Sun, Xiaoling (2016). "Usage patterns of scholarly articles on Web of Science: a study on Web of Science usage count". Scientometrics, v. 109, n. 2, pp. 917-926.

https://doi.org/10.1007/s11192-016-2093-0

Williams, Virginia-Kay (2010). "Issues in determining cost for cost per use calculations". Procedings of the Charleston Library Conference.

https://doi.org/10.5703/1288284314838

Zhu, Qiandong; Xiang, Huimin (2016). "Differences of Pareto principle performance in e-resource download distribution". The electronic library, v. 34, n. 5, pp. 846-855.

https://doi.org/10.1108/EL-05-2015-0068

\section{Colección de libros de bolsillo El profesional de la información (Editorial UOC) Últimos títulos publicados}
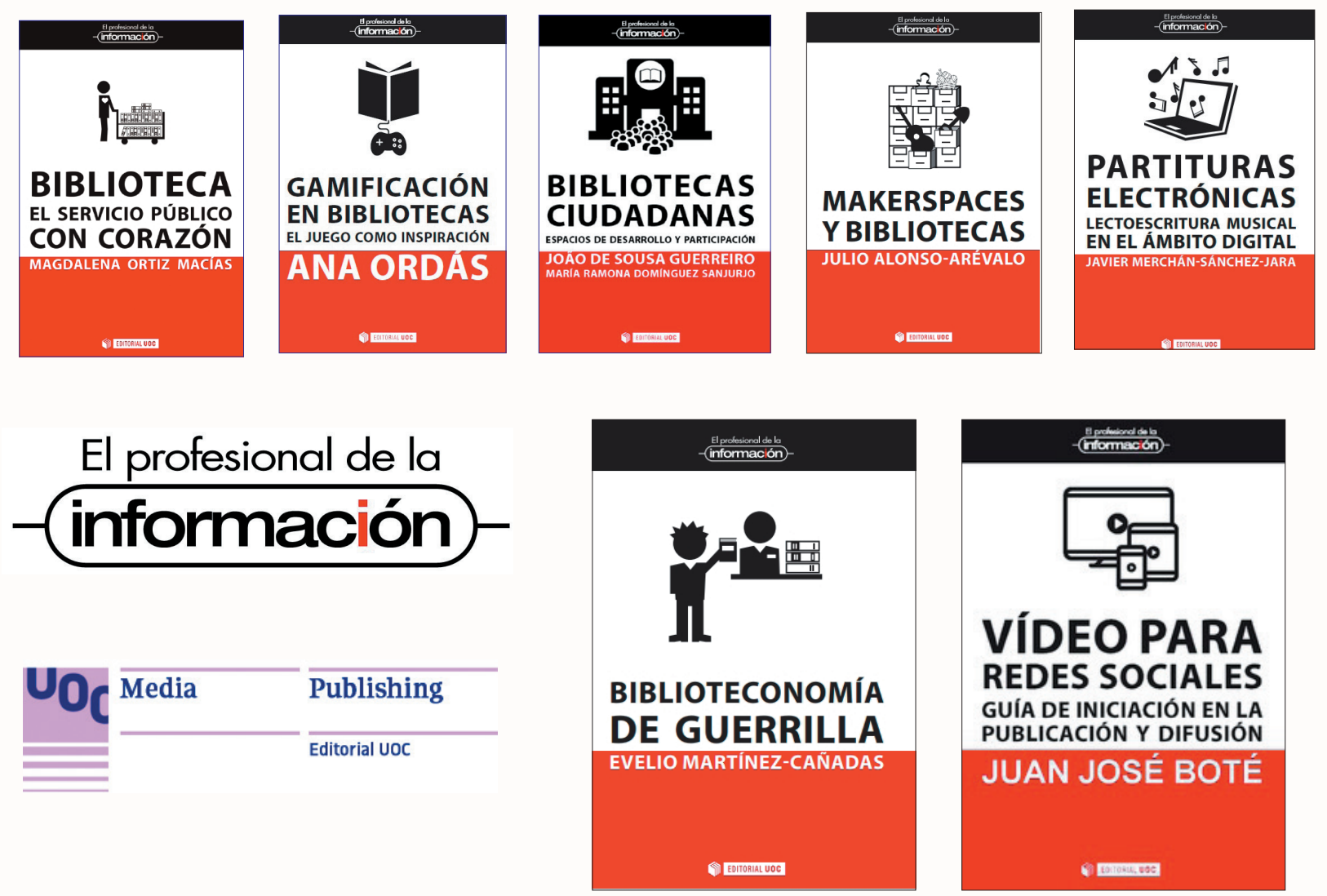

Más información:

http://www.elprofesionaldelainformacion.com/libros.html 


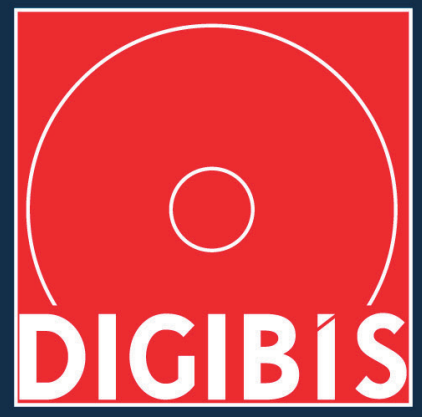

Nuestra vocación: contribuir a que el patrimonio cultural español sea preservado digitalmente y se difunda de la manera más amplia posible

Con metadatos ajustados a la normativa internacional

Aplicaciones Linked Open Data (LOD) con Reconciliación Semántica

Aplicaciones que pueden incorporar Recolector y Repositorio OAI-PMH

Aplicaciones pensadas y desarrolladas para hacer más eficiente y ágil el trabajo de los administradores y más comprensible para el usuario el acceso a los recursos catalogados. 